\title{
Solutions for adapting photovoltaics to large power irrigation systems for agriculture
}

\author{
L. Narvarte , J. Fernández-Ramos , F. Martínez-Moreno ，L.M. Carrasco , R.H. Almeida , \\ I.B. Carrêlo
}

\begin{abstract}
A B S T R A C T
The adaptation of the mature PV water-pumping technology to large power irrigation applications requires the problems associated to PV power intermittencies and matching PV production with the irrigation needs to be resolved. This paper presents the innovations developed, implemented and tested in a PV irrigation prototype installed in a real well at an Irrigator Community in Alicante, Spain. The innovations eliminate the intermittences due to passing clouds, reducing the PV power by $80 \%$ in just few seconds without batteries, just using control algorithms in the frequency converter, avoiding water hammers and overvoltages. A North-South horizontal axis tracker has been used to extend the number of hours of irrigation per day and to provide daily constant profiles of PV power during the irrigation period. Moreover, the use of this tracker allows the nominal power of the PV generator to be reduced by $45 \%$ as compared to a fixed structure for the same volume of water. The analysis of the economic feasibility of the prototype compared with the cost of grid electricity shows savings of $60 \%$. This prototype has been operating in the South of Morocco delivering more than $235 \mathrm{~m}^{3} /$ day for the last three years.
\end{abstract}

\section{Introduction}

Photovoltaic (PV) irrigation is becoming more and more interesting due to the high energy costs of modernized irrigation systems for productive agriculture, not only in Southern Europe [1] but all also in other regions of the world [2].

PV water pumping reached maturity from its first application [3] in the mid 1970s, when Dominique Campana built a PV water-pumping system in Corsica. Father Bernard Vespieren was among the visitors to this first experience and, enthused by the good performance of the pump, insisted on using it to solve drinking water problems in Mali. To this end, he designed and carried out the "Mali Aqua Viva" Project which, in 1981, put 25 pumping systems into operation [4]. After this first experience, many other PV pumping programmes were developed [5-7], not only in different regions of Africa (Morocco [8-10], Sahel countries [11] or Western Africa [12]), but also in North America $[13,14]$, South America [15,16] and Asia [17,18]. A great effort to assure their long-term reliability was made by drawing up good-practice guidelines and technical specifications [19-22]. In this regard, the experience of the Regional Sahel Program, that installed 600 PV pumps to provide drinkable water to 1 million people, was particularly interesting because it developed exhaustive technical specifications and quality control procedures with remarkable results [23-26]. In parallel, new developments allowing standard frequency converters and centrifugal pumps to be used, reduced the cost and increased the reliability [27-30]. This long experience was limited to providing clean water to the population or small-scale irrigation systems with relatively lowpower PV systems typically between $500 \mathrm{Wp}$ and $5 \mathrm{kWp}$.

Now, the adaptation of PV water-pumping systems to the irrigation needs of farmers, irrigator communities and agro-industries requires the PV peak power to be enlarged to encompass the range of $20 \mathrm{kWp}-500 \mathrm{kWp}$ and to solve two main challenges identified by EIP water [31].

The first one is the intermittent character of PV power. This variability makes it unsuitable for irrigation applications where a higher PV power is required, mainly for two reasons: the variation in solar irradiance throughout the day that can be calculated mathematically, and passing clouds that randomly reduce the PV power. The latter is not only a matter of aesthetics but a key aspect in terms of the reliability of large power PV irrigation systems. The instability produced in the 


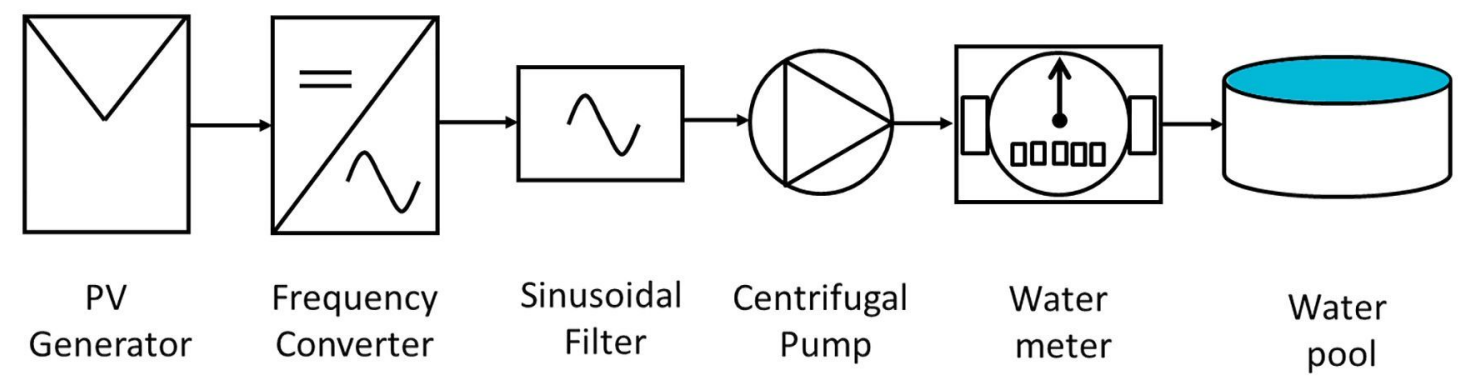

Fig. 1. Schematic of the PV irrigation system.

control system due to an abrupt decrease in PV power makes the frequency converter stop suddenly, with two main damaging effects. On the one hand, the large water flow and the deep pumping sources give rise to strong water hammers which can damage the hydraulic system, reducing its lifetime. On the other hand, the abrupt stop together with the long lengths of wires between the frequency converter and the submergible pump cause overvoltages that can damage both the frequency converter and the submergible motor-pump.

The most direct and intuitive pathway for reducing the PV intermittencies is the use of auxiliary sources of power when the PV source is not enough, or by implementing complex and expensive equipment such as batteries to uncouple the PV energy production and energy delivery. The higher cost, the complexity, and therefore, the lack of reliability have been barriers for the market uptake of these systems.

The second challenge is the match between PV energy production and water needs for irrigation. On the one hand, the irrigation period usually lasts three months before and after the summer solstice, so the monthly PV production should be maximised during this period. On the other hand, on a daily basis, the good performance of both the water source and the hydraulic system, require constant daily profiles of water flow. This is crucial for the case of so-called "direct pumping", where constant-pressure devices such as sprinklers, pivots or drip systems are used for irrigation. Obviously, the daily profile of a PV generator installed on a fixed structure facing the Equator (South in the Northern hemisphere; North in the Southern hemisphere) does not fulfil this requirement.

This paper presents two innovations that tackle both challenges. On the one hand, this paper presents a new solution for solving the problems associated with the PV power intermittences without using batteries, just using control algorithms in the frequency converter that support the abrupt PV power fluctuations due to passing clouds, taking advantage of the possibility of power regeneration of the centrifugal pumps [32]. On the other hand, North-South horizontal axis solar trackers have been used to maximize the water pumped during the irrigation period, to extend the number of hours of irrigation per day and to produce constant daily profiles that match the well dynamics better. Although this tracker is well known $[33,34]$, its application in PV irrigation is a novelty with very good results, such as the reduction in the required PV power for a certain demand of water by $45 \%$ as compared to a fixed structure (see "Matching PV production and irrigation needs").

These solutions have been implemented and tested in a prototype installed in a real well at the Irrigator Community of Alto Vinalopó (Alicante, Spain), pumping from a borehole $253 \mathrm{~m}$ deep to a water pool [35]. The results presented in this paper show a great technical reliability and a dramatic reduction in the cost of energy (60\% as compared to the use of conventional grid electricity).

These solutions allow the power to be extended and PV pumping technology adapted to large power irrigation applications. Their impact can be very high as agricultural irrigation is a high electricity consuming activity. We estimate a total consumption of $24,000 \mathrm{GWh} /$ year in Southern Europe [36-38], which means a potential market of 16 GWP of PV irrigation systems, representing €24,000 M of investment.
After these tests, the prototype was installed in Tizi, a small village in the South of Morocco, in 2014 to provide water to irrigate 30 ha of olive trees, plum trees and saffron. The system is still working and results on its performance under real operating conditions are also shown.

\section{Methodology: Development and testing of solutions in a prototype}

The methodology for developing and testing the technical solutions was based on installing the prototype of a PV irrigation system in a real well of a productive farm. A $20 \mathrm{kWp}$ PV irrigation prototype was installed in 2013 in the "Candela" borehole of the Irrigator Community of Alto Vinalopó (Alicante, Spain). The borehole was $253 \mathrm{~m}$ deep and it was previously used to pump to a water pool using the grid. In 2012, this well worked $2613 \mathrm{~h}$, consuming $958,939 \mathrm{kWh}$ to pump $738,679 \mathrm{~m}^{3}$, paying a total bill of $€ 94,247$ to the utility company for this service.

The grid was substituted by a $20 \mathrm{kWp}$ PV pump with the following characteristics:

- 80 ATERSA A-250P SOL PV modules of $250 \mathrm{Wp}$ each.

- Two $10 \mathrm{~kW}$ SOLTEC North-South horizontal axis trackers.

- A $18.5 \mathrm{~kW}$ OMRON frequency converter model 3G3RX-A4185-E1F

- A $15 \mathrm{~kW}$ CAPRARI E6XB30/47 submersible electrical pump.

As the wiring between the output of the frequency converter and the motor-pump was too long, a sinusoidal filter was also inserted. Fig. 1 shows a schematic of the system and Fig. 2 shows the PV generator mounted on the North-South horizontal axis tracker (hereafter a N-S tracker) and the frequency converter.

Two main innovations were included in this prototype. The first one was to develop and implement control algorithms in the frequency converter to assure its stability, that is, to avoid sudden stops even when clouds give rise to solar power intermittences. Frequency converters in PV pumping systems control the operating voltage of the PV generator and the frequency of the centrifugal motor-pump with a ProportionalIntegral-Derivative controller (PID) [39]. Furthermore, they usually have routines for tracking the maximum power point voltage of the PV generator in order to maximize PV production [40-43]. Normally, the PID parameters are tuned to allow a stable performance on clear-sky days [28], but this tuning cannot keep the frequency converter stable when a sudden fall of irradiance takes place, stopping abruptly and producing water hammers and overvoltages between the frequency converter and the motor-pump which reduce the lifetime of the system. In order to avoid these problems associated with PV power intermittences, an algorithm to avoid sudden stops has been implemented in the control of the frequency converter. The control algorithm consists of the following steps:

Step 1) To detect an irradiance fluctuation as soon as possible. The detection is done by monitoring the $\mathrm{DC}$ voltage in the internal DC bus of the frequency converter. When a cloud passes, the DC voltage decreases rapidly. When the DC voltage decreases below $500 \mathrm{~V}$, Step 2 is activated. For this detection, it is necessary to have a feedback control signal without delay. Standard frequency converters offer 

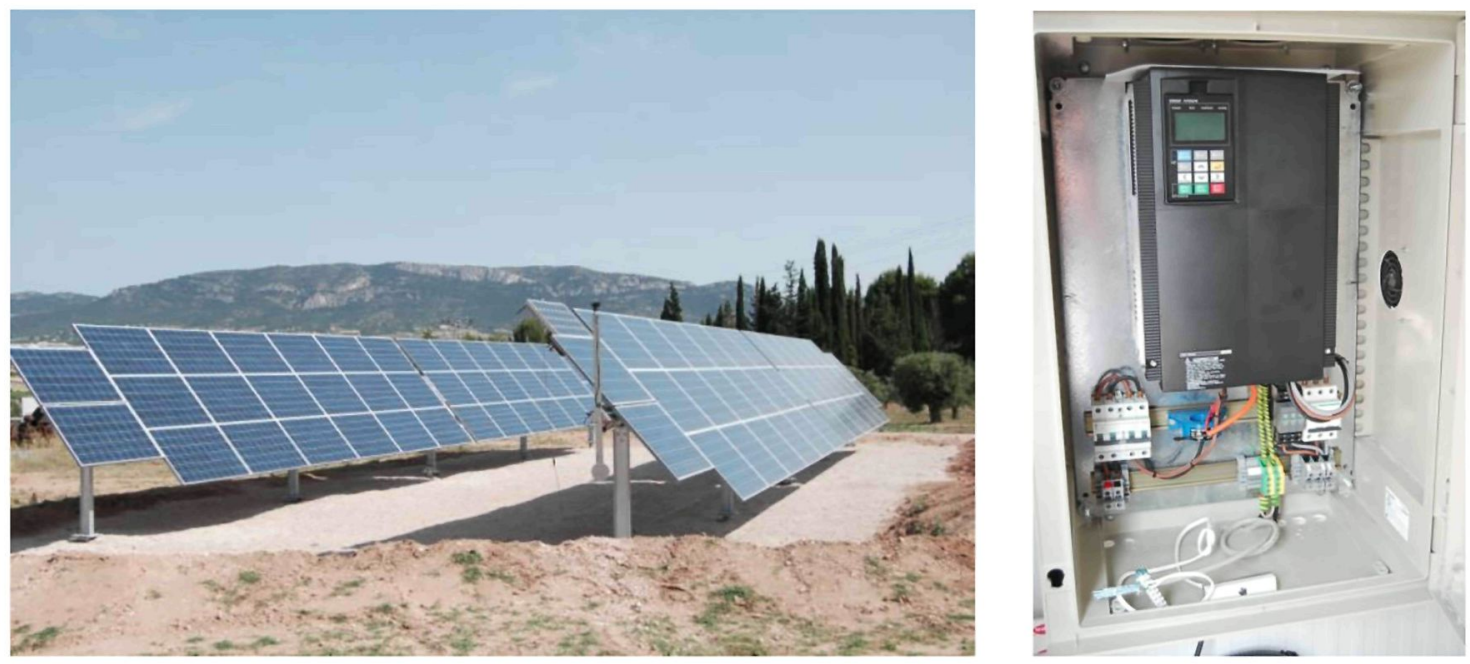

Fig. 2. $20 \mathrm{kWp}$ PV generator mounted on a North-South horizontal axis tracker (left) and a standard frequency converter used to control and feed a standard centrifugal motorpump (right).

feedback signals of the internal DC voltage with delays in the range of $100 \mathrm{~ms}$, which is excessive for reacting against an irradiance fluctuation. So, in our prototype, a direct and fast sensor of the DC voltage has been added to the frequency converter.

Step 2) Once the fall in irradiance is detected, the PID controller is deactivated and the output frequency is reduced to produce power regeneration in the centrifugal pump to keep the voltage of the DC bus of the frequency converter stable. This avoids the DC voltage decreasing to below the minimum operating voltage of the frequency converter and, therefore, avoiding its sudden stop.

Step 3) If the cloud passes, the PID controller is restored with the original parameters for normal operation. If the cloud stays, then a soft controlled stop is done with a deceleration ramp.

The second innovation is the use of the N-S tracker. Although this tracker has been used in the past in big PV plants [44-46], it is the first time that it has been used in PV irrigation systems, showing numerous advantages for this application. The matching between the yearly water demand for irrigation and the yearly profile of water pumped using this $\mathrm{N}-\mathrm{S}$ tracker is much better than with the use of just a static fixed structure. Moreover, this N-S tracker offers a constant daily profile of pumped water during the irrigation period, which matches the well dynamics better, and allows the threshold power to be reached to start pumping much earlier in the morning and much later in the afternoon, allowing more pumping hours per day. These advantages are analysed in greater depth in "Matching PV production and irrigation needs".

The prototype was monitored from June to September 2013, the most demanding months in terms of irrigation, and its main performance variables were recorded in order to analyse its behaviour with the monitoring system shown in Fig. 3, made up of a Yokogawa model WT 1600 wattmeter and a personal computer to store the data. They allowed data to be registered every $4 \mathrm{~s}$ : effective irradiance on the PV generator, $G$, and effective solar cell temperature, $T c$ (these two variables come from a calibrated PV module [47]; DC power at the input of the frequency converter, $P_{\mathrm{DC}}$ (a class 0.5 shunt resistor with a ratio $30 \mathrm{~A} / 150 \mathrm{mV}$ was used to measure the DC current accurately); operating $\mathrm{DC}$ voltage, $V_{\mathrm{DC}}$; three-phase $\mathrm{AC}$ power at the output of the frequency converter, $P_{\mathrm{AC}}$ (Yokogawa model 96,001 current-clamps); operating frequency, $f$; pumping head, $H_{\mathrm{T}}$; and water flow, $Q$. The analysis of the monitoring data to test the good performance of the solutions is discussed in "Results".

The economic analysis has been carried out by comparing the actual cost of pumping from this well with the grid during 2012, and the current cost with the PV prototype. In order to evaluate the latter, we

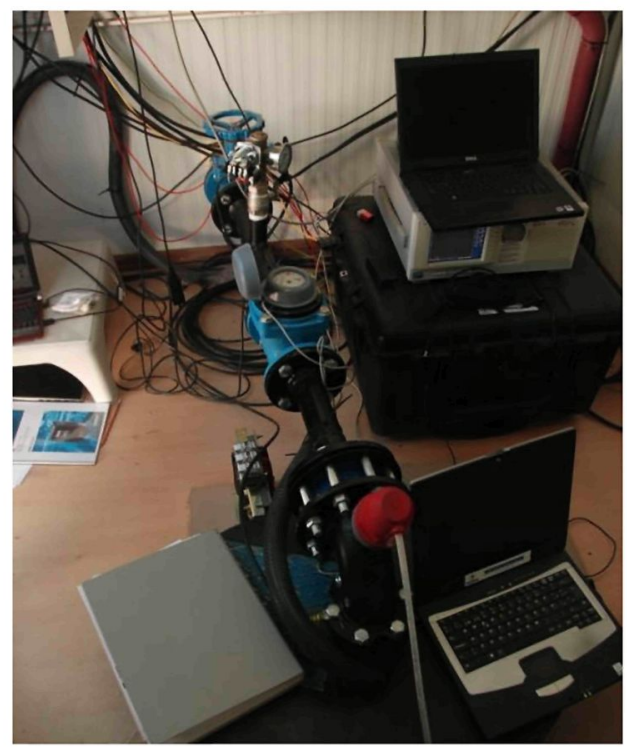

Fig. 3. View of the monitoring system.

Table 1

Scenario for the evaluation of economic feasibility.

\begin{tabular}{lll}
\hline Item & & Values \\
\hline PV irrigation system cost $(€ / \mathrm{Wp})$ & $C_{P V i s}$ & 2.22 \\
Interest rate $(\%)$ & $r$ & 5 \\
Discount rate $(\%)$ & $d$ & 3.5 \\
Grid electricity tariff $(€ / \mathrm{kWh})$ & $a$ & 0.13 \\
Energy production in year i $=0 .(\mathrm{kWh})$ & $E a_{0}$ & 41,595 \\
PV degradation rate $(\% /$ year) & $D_{P V}$ & 0.8 \\
PV power generator $(\mathrm{Wp})$ & $P_{P V}$ & 20,000 \\
$100 \%$ credit & & 10 years \\
& & 25 years
\end{tabular}

have considered a period of 25 years of amortization with two different financing scenarios (100\% of the cost during 10 and 25 years) and with the framework detailed in Table 1.

In order to calculate the cost of the kWh produced with the PV irrigation systems, the following equations have been used. The payments to amortize the credit $(K)$ for $n$ financing years are: 
$K(€)=\sum_{i=1}^{n} \frac{\left(\frac{c_{P V i s} \cdot P_{P V}}{n}\right) *(1+[n-1] * r)}{(1+d)^{i}}$

So, the calculation of the cost of the PV electricity for a period of 25 years is calculated as follows:

$P V_{\text {cost }}\left(\frac{\mathrm{c} €}{\mathrm{kWh}}\right)=\frac{\frac{K}{100}}{\sum_{i=1}^{n} E a_{i}}$

Once the solutions were ready, the PV irrigation system was transported to a small village in the South of Morocco where it has been working since February 2014. Some commissioning tests were carried out and the person responsible for irrigation in the village was trained to manage the PV irrigation system and to register the daily water pumped and the technical incidences of the system. The results of the tests and the performance of the system from February 2014 to January 2017 are shown in "Installation and operation of the prototype in Morocco".

\section{Results}

Robustness against PV power intermittences due to passing clouds

Once the new control algorithms to avoid instabilities in the frequency converter due to PV power intermittences were adjusted to our prototype, it was evaluated during the month of September 2013 as this month usually has a significant proportion of days with passing clouds in this region. In Fig. 4 the main operation variables $\left(G, P a c, f\right.$, and $\left.V_{\mathrm{DC}}\right)$ are shown throughout the representative day 19th September 2013, which was a day with PV power fluctuations around midday. Figs. 5-7 show the details of three PV power fluctuations at $13: 50 \mathrm{~h}, 14: 02 \mathrm{~h}$ and $14: 12 \mathrm{~h}$, respectively (for clarity, $P_{\mathrm{DC}}$ is not plotted in these figures because it is similar to $P_{\mathrm{AC}}$ ). As can be observed, although the irradiance and output power fluctuations are intense (from approximately $870 \mathrm{~W}$ / $\mathrm{m}^{2}$ to $100 \mathrm{~W} / \mathrm{m}^{2}$ in just few seconds), the frequency is reduced but never goes down to zero, which means that the converter does not become unstable and it does not stop.

Obviously, these algorithms do not eliminate the PV power fluctuations (that could only be absorbed with accumulation systems, usually big for irrigation and, therefore, requiring a large investment), but they remove their harmful consequences.

Recent publications $[48,49]$ have shown that a PV generator acts as low-pass filter whose input is the solar irradiance and the output is the delivered power. Its bandwidth depends on the size of the PV generator. So the bigger the PV generator, the bigger the attenuation of the irradiance fluctuations. Therefore, the effect of passing clouds on the reduction of the available power from a $20 \mathrm{kWp}$ PV generator will be sharper than on a larger PV generator and, consequently, if this solution works correctly with this size, it will also work in bigger sizes.

\section{Matching $P V$ production and irrigation needs}

In order to match the PV production and the water needs for irrigation, the $20 \mathrm{kWp}$ PV generator was mounted on a N-S tracker, designed and installed under the current state-of-the-art specifications but including a small stand-alone PV system to allow the tracker movement without grid supply. Fig. 8 shows this stand-alone PV system made up of two $10 \mathrm{Wp} \mathrm{PV}$ modules, a charge regulator and four $6 \mathrm{~V}$-batteries with a capacity of $12 \mathrm{Ah}$, fully integrated into the N-S tracker.

In order to compare the monthly amount of water pumped by the same PV generator mounted on three different structures, optimum tilted static, N-S and ideal two axis trackers, a simulation was carried out using the SISIFO simulation tool [50] for a whole year and at the location of the prototype (latitude: $38.654^{\circ}$, longitude: $-0.085^{\circ}$ ). Fig. 9 shows the results. It can be observed that the N-S tracker has a performance very similar to the ideal one during the months with irrigation (from April to September), but it is much cheaper and requires much less maintenance [51]. It has a very similar performance to the static system in the winter months, but then it is not necessary to irrigate. A brief analysis of these values shows that, in order to get the same volume of pumped water during July, which is the most critical month for irrigation, the static system would need $45 \%$ more PV peak power than the N-S tracker $[(250.3 / 172.6)=1.45]$. Furthermore, adding a second axis to the tracking system would reduce the power by $11 \%$ $[(277.3 / 250.3)=1.11]$. The economic impact associated to these

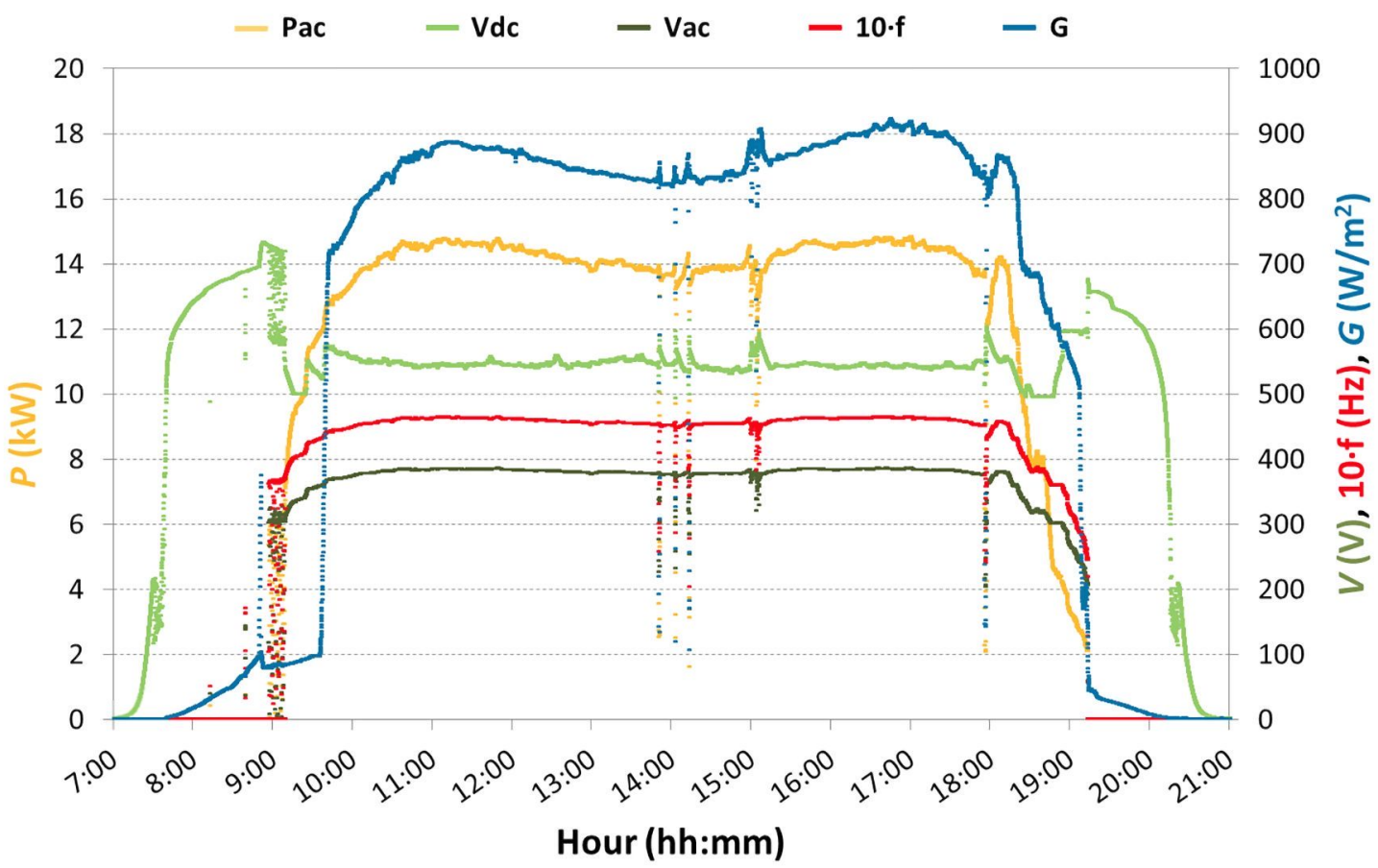

Fig. 4. Main operation variables of the PV irrigation system (Irradiance, $G$; frequency converter output power, Pac; frequency, $f$; and operating DC voltage, $V_{\mathrm{DC}}$ ) throughout the representative day 19th September 2013. 


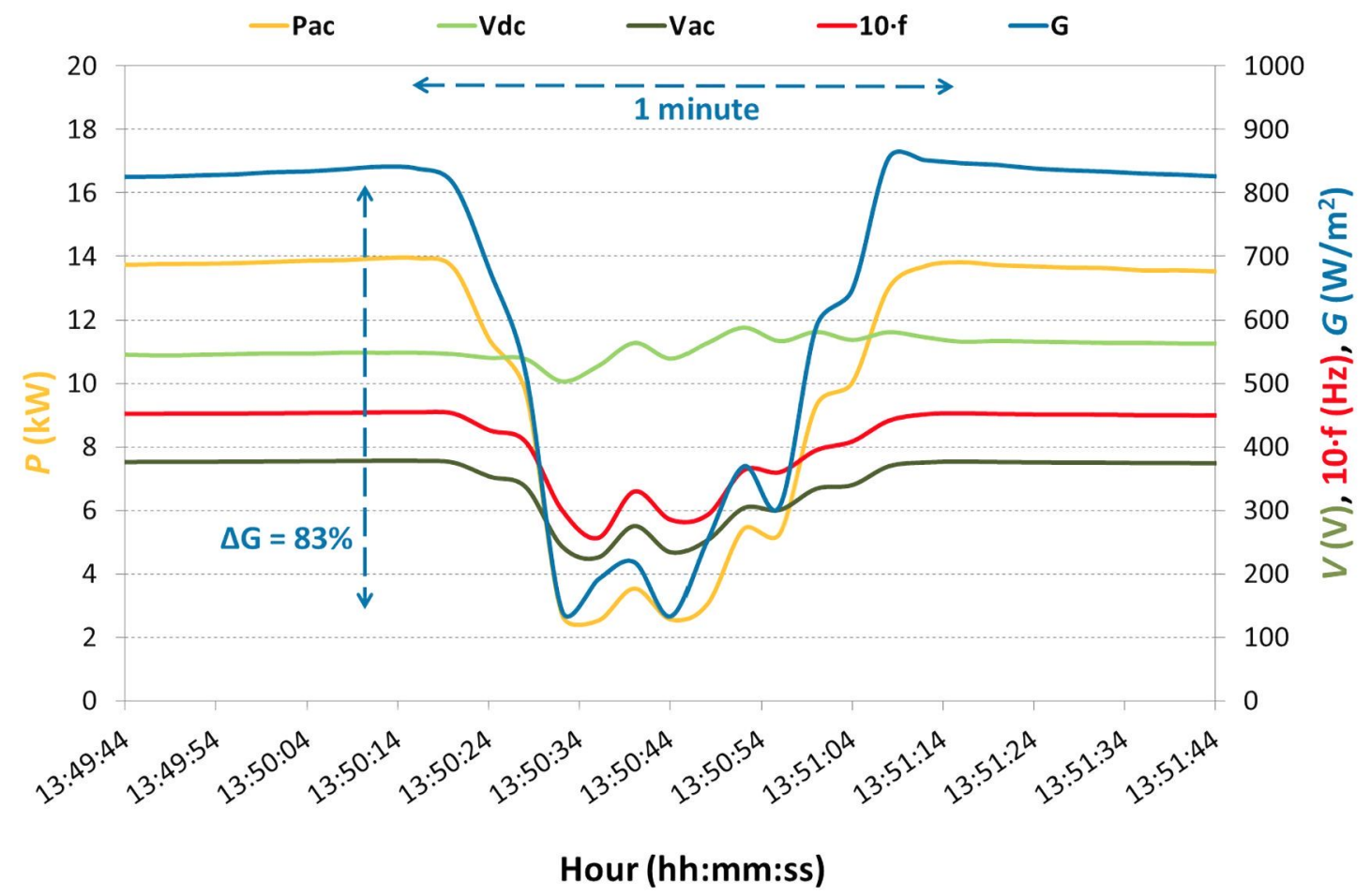

Fig. 5. Detail of the fluctuations of the main operation variables at $13: 50 \mathrm{~h}$.

differences depends on the relative prices of photovoltaic modules and trackers, but any realistic scenario suggests dismissing the use of twoaxis tracking. Currently installed N-S tracker prices are around $0.2 €$ / $\mathrm{Wp}$ [52], and PV module prices are around $0.5 € / \mathrm{Wp}[53,54]$. In this scenario, the use of this tracker is economically advantageous.

On the other hand, solar tracking offers advantages when either pumping from low flow rate wells or constant pressure direct pumping are concerned. In both cases constant pumping daily profiles are needed to avoid stressing the well with sharp daily peaks of water flow and to provide constant PV power respectively, and this daily profile is provided by the N-S tracker.

The second advantage is that the pumping time is extended. Fig. 10 compares the simulated daily profiles of water flow pumped to a water pool during the summer solstice. The N-S tracker allows pumping to begin earlier in the morning and until later in the evening: it starts at 05:20 and finishes at 18:40, while the static structure with the same

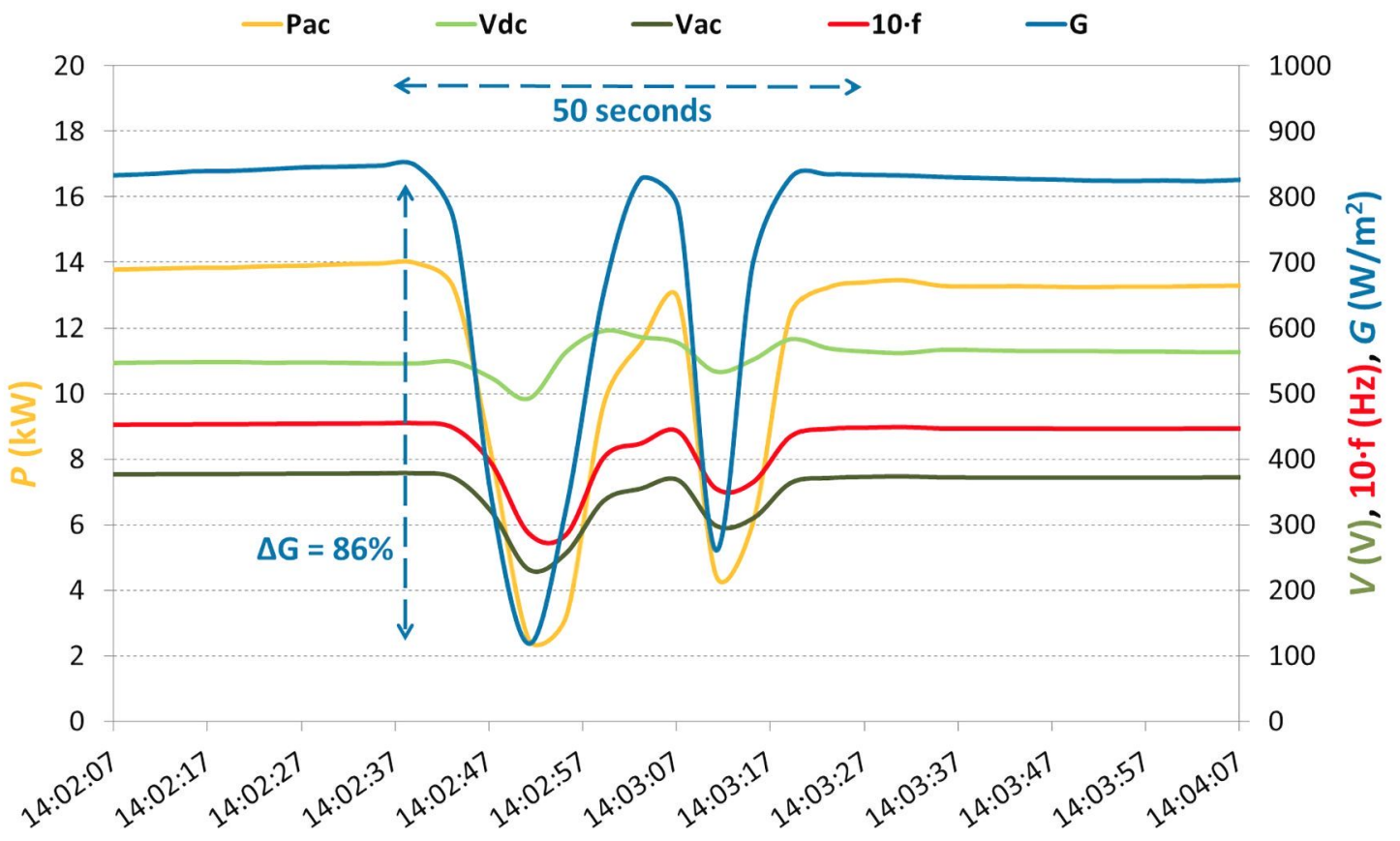

Hour (hh:mm:ss)

Fig. 6. Detail of the fluctuations of the main operation variables at 14:02 h. 


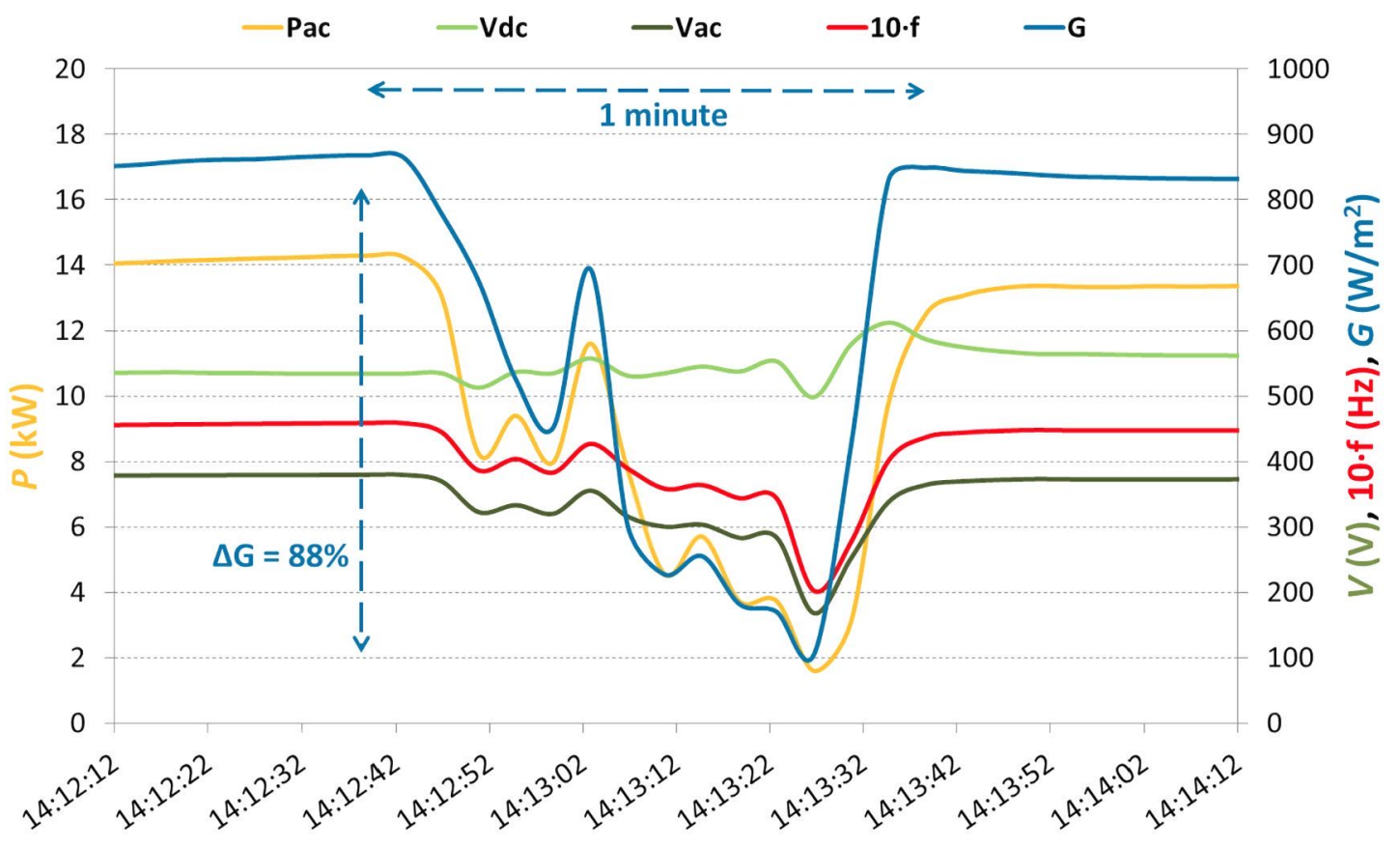

Hour (hh:mm:ss)

Fig. 7. Detail of the fluctuations of the main operation variables at $14: 12 \mathrm{~h}$.
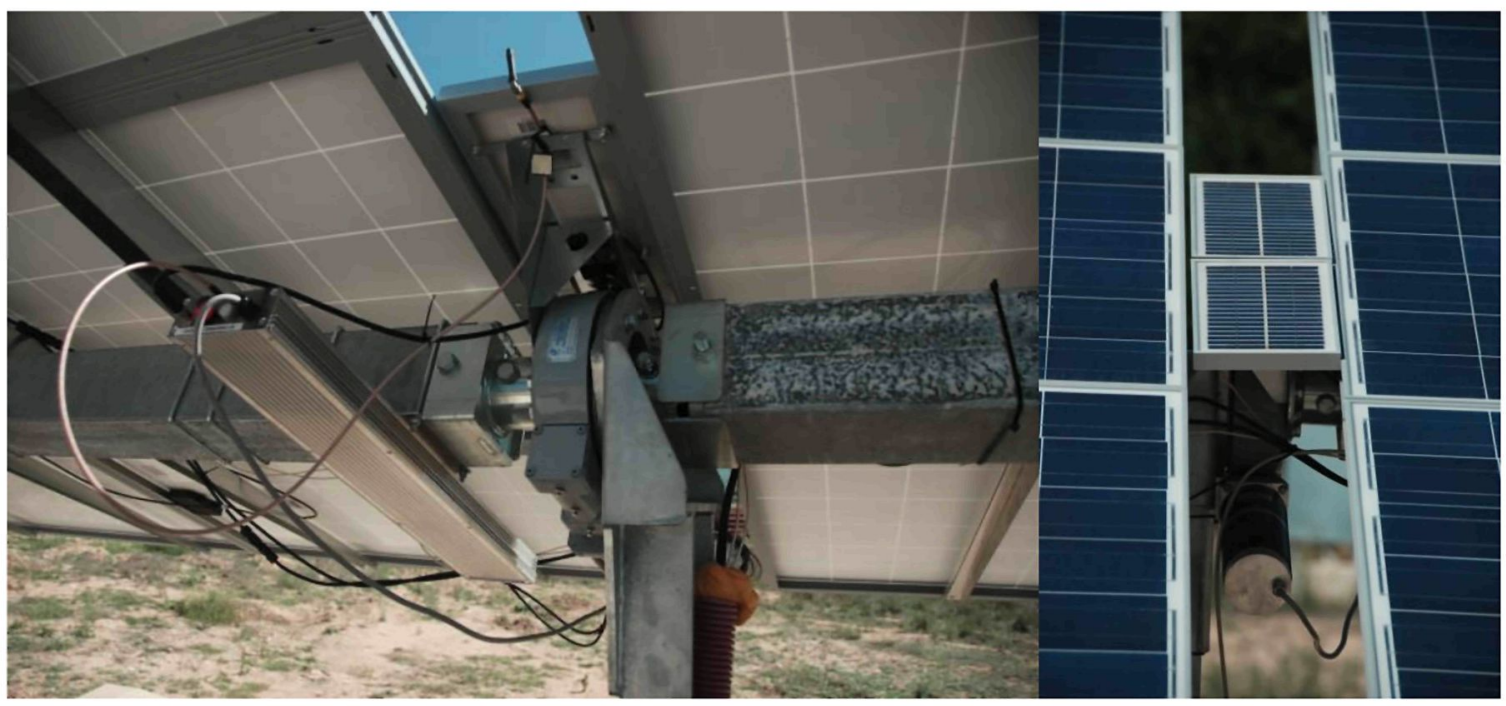

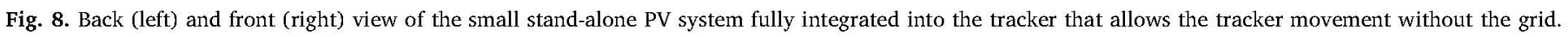

peak power starts at 06:20 and finishes at 17:30 (all of them in solar time), which represents $2 \mathrm{~h}$ and $10 \mathrm{~min}$ more pumping time.

The third advantage is that it requires less nominal power to pump the same volume of water than a PV generator mounted on a static structure. Fig. 11 shows the daily profile of PV power for these two cases: an N-S tracker, and a static South-oriented generator, tilted at $20^{\circ}$. The nominal power of each of the two PV generators is that needed to equal the volume of water pumped in July. When compared to the N$S$ tracker, the South-oriented generator requires $45 \%$ more nominal power to pump the same volume of water on the characteristic day in July. The figure shows the power throughout this day in relative terms to that delivered by the N-S tracker at noon $\left(p_{u}\right)$. From this figure, it can be deduced that the well must have a $45 \%$ greater flow rate with the static generator facing South than with the N-S tracker, which could stress out the well.
Performance analysis

The performance analysis of the $20 \mathrm{kWp}$ prototype described in "Methodology: Development and testing of solutions in a prototype" is based on experimental data on the operation from June to September 2013. Fig. 12 shows the evolution of the efficiencies of the PV generator, frequency converter and motor-pump together with the overall efficiency of the system over three representative days (from 19th to 21st September 2013). The efficiency values during the whole monitoring campaign are summarized in Table 2.

The efficiency of the whole system, defined as the ratio of the hydraulic energy and the total irradiation during the period, reaches $7.1 \%$, and the good performance of the devices is remarkable taking into account that they are working at a variable frequency. Again, the flat profile of PV power with the N-S tracker contributes to an operation 


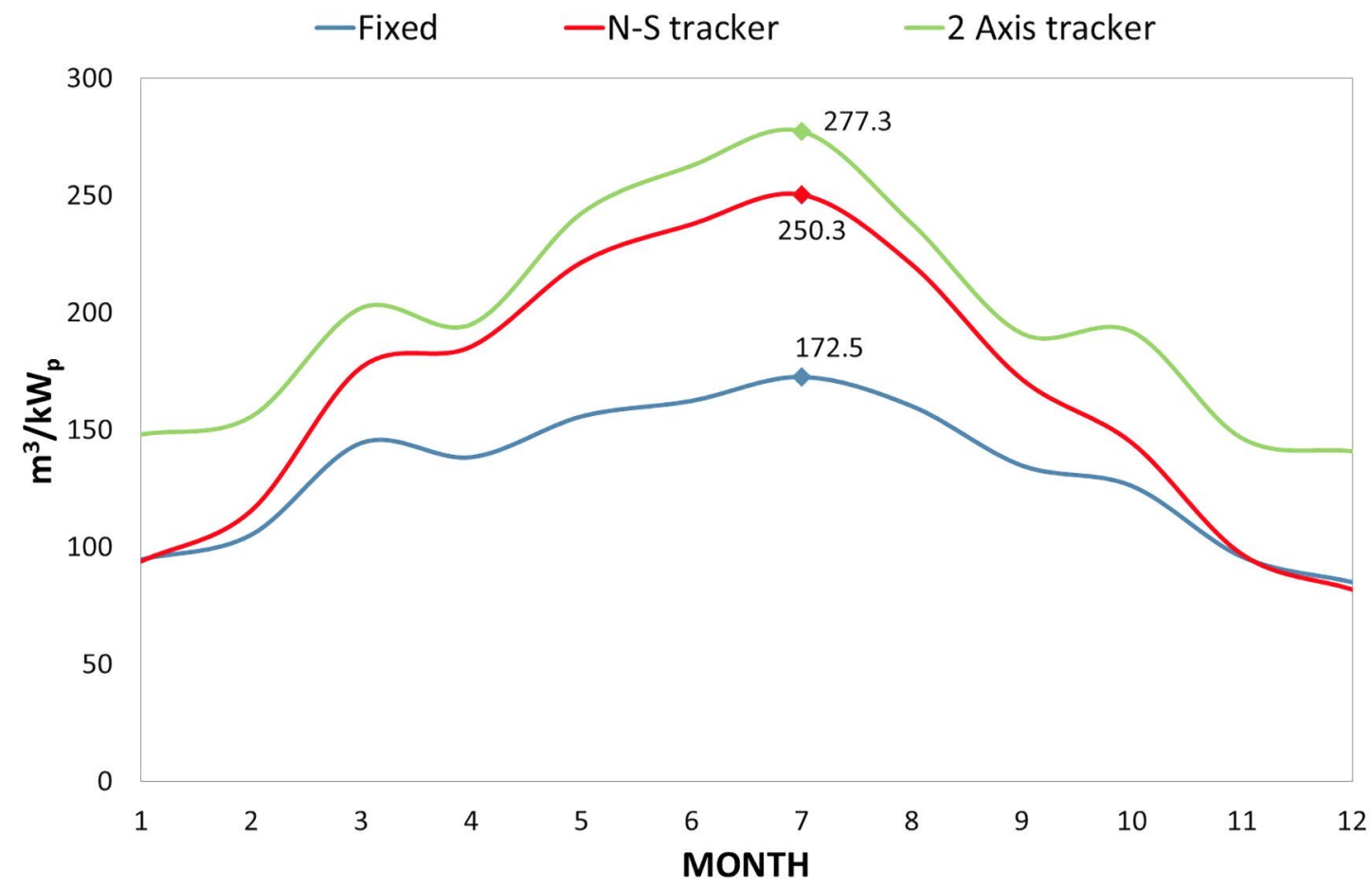

Fig. 9. Comparison of the pumped water volume throughout the year of the same PV generator mounted on three different structures: optimum tilted South facing fixed structure (blue), North-South horizontal axis tracker (red) and two axis ideal tracker (green). (For interpretation of the references to colour in this figure legend, the reader is referred to the web version of this article.)

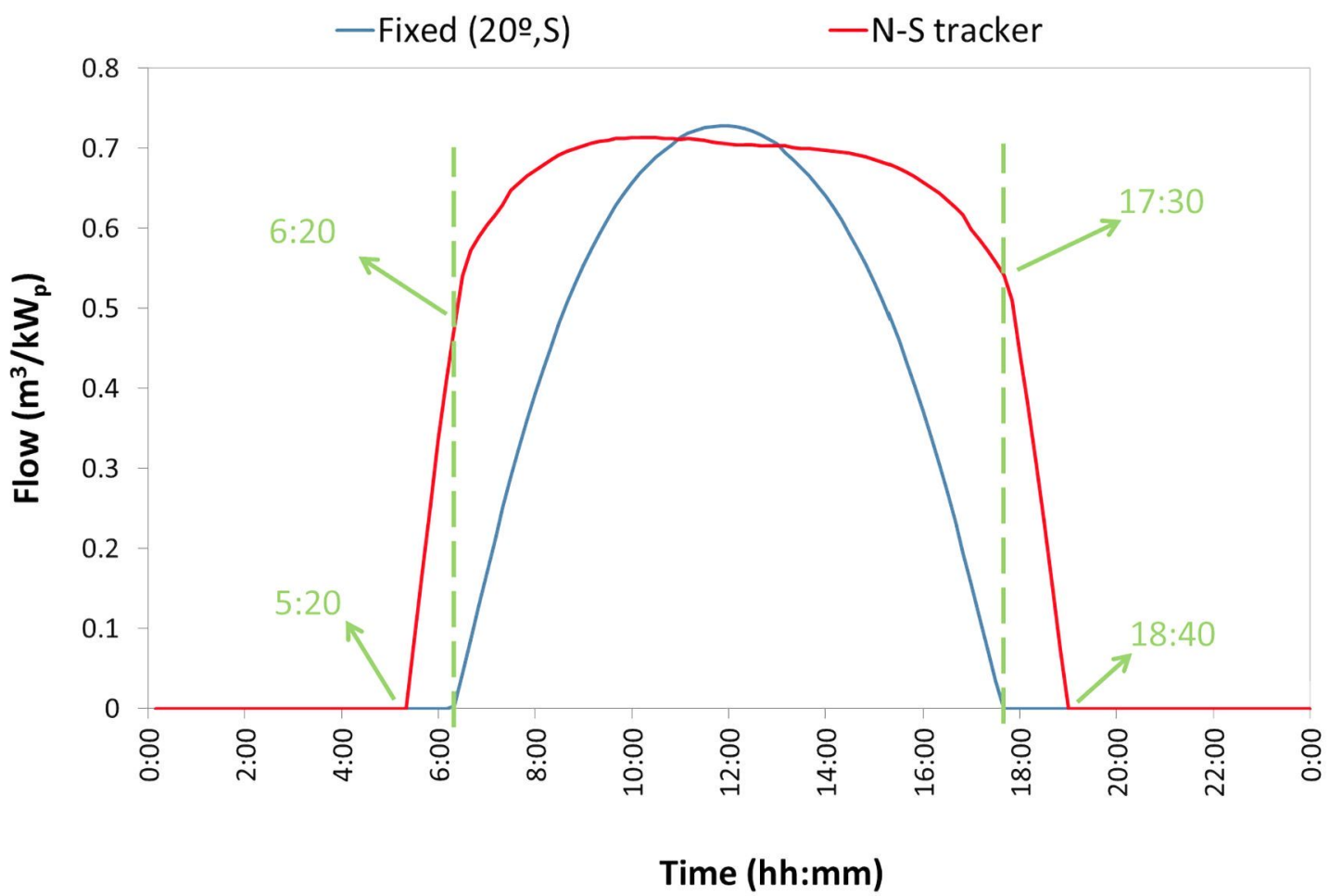

Fig. 10. Comparison of the daily profile of water flow supplied by a fixed structure (blue) and by a North-South horizontal axis tracker (red) with the same peak power (June). Time is expressed in intervals of $10 \mathrm{~min}$. (For interpretation of the references to colour in this figure legend, the reader is referred to the web version of this article.)

near to the set point during most of the day, where the performance of the devices is better.

In order to quantify the quality of the system we have used the performance ratio index [55], PR, but using the hydraulic energy as the output of the system (see Eq. (3)). The resulting value is 0.456 .
$P R=\frac{E_{\mathrm{H}}}{P * \int\left(G / G^{*}\right) d t}$

In Eq. (3), $P^{*}$ is the nameplate PV power of the generator, $G^{*}$ is the irradiance under Standard Test Conditions $\left(G^{*}=1000 \mathrm{~W} / \mathrm{m}^{2}\right), E_{\mathrm{H}}$ is the 


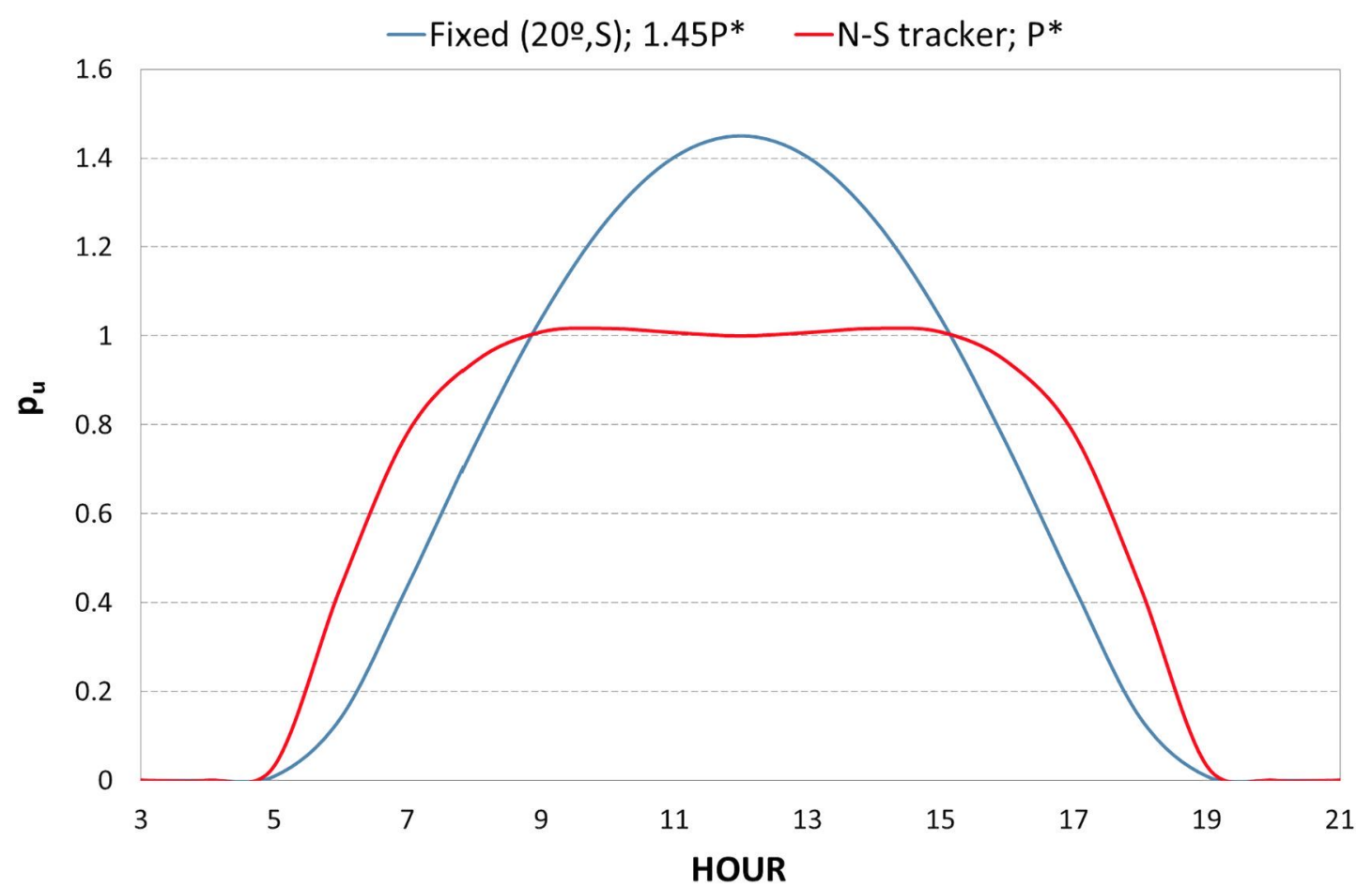

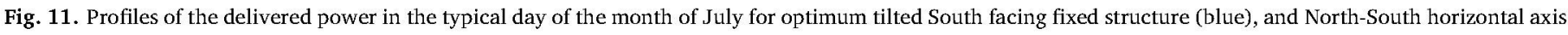

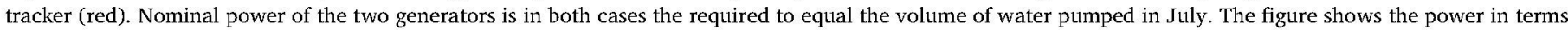

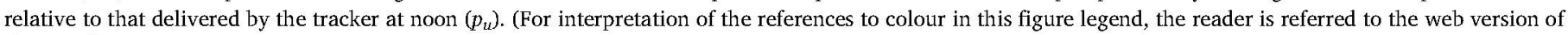
this article.)

hydraulic energy related to the water pumped during the test period and $G$ is the effective irradiance measured in the plane of the generator during the same period.

It is worth noting that these experimental data allow us to characterize some operating modes. For example, Fig. 13 shows the frequency - DC power curve. It can be observed that this relationship is linear from $6 \mathrm{~kW}$. Below this power, the curve is affected by the start/ stop behaviour that is influenced by the state of charge of the pipe in the well. In the first start, when the pipe is empty, more power is necessary for a certain frequency: for example, in order to achieve $30 \mathrm{~Hz}$, $5 \mathrm{~kW}$ are needed (right curve under $6 \mathrm{~kW}$ ). The power when the pipe is empty is higher because the pump "sees" more height. On the other

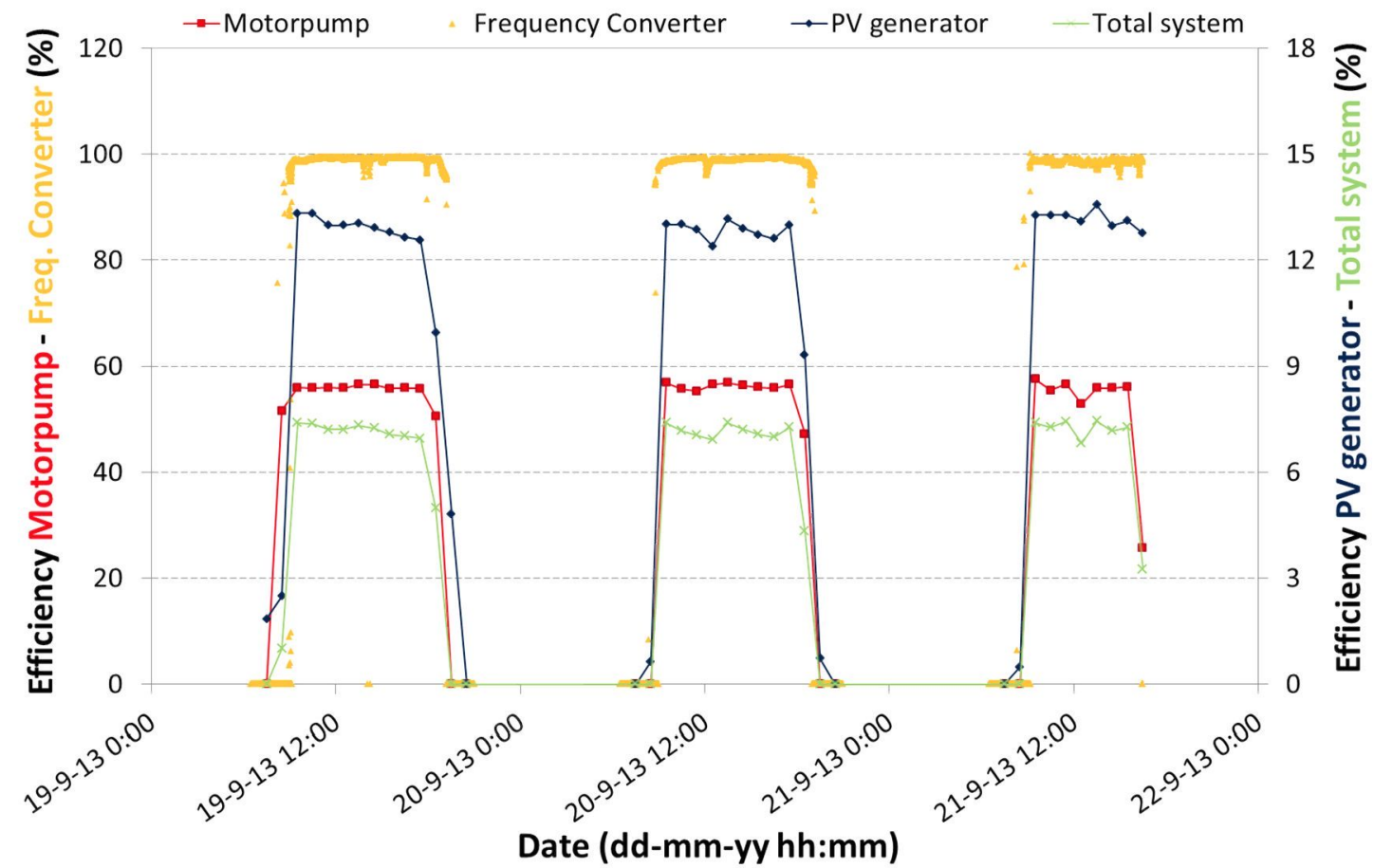

Fig. 12. Evolution of efficiency over three representative days. Motor-pump and frequency converter efficiencies are referred to the left axis and PV generator and Total system to the right one. 
Table 2

Efficiency of the devices and the overall system during the whole monitoring period (from June to September 2013).

\begin{tabular}{ll}
\hline Device & Efficiency (\%) \\
\hline PV generator & 13.2 \\
Frequency converter & 98.9 \\
Motor-pump & 54.2 \\
Total system & 7.1 \\
\hline
\end{tabular}

hand, when the pipe is full, the pump "sees" less height and requires less power: the frequency of $30 \mathrm{~Hz}$ can be supported with just $3 \mathrm{~kW}$ of power (left curve under $6 \mathrm{~kW}$ ). This fact must be considered to establish the threshold of available PV power to take the decision to start the pump as the pump manufacturer recommends not operating the pump under $30 \mathrm{~Hz}$

\section{Economical feasibility}

The results of the comparison of the electricity cost of pumping with the grid during 2012 and the current electricity cost with the PV prototype are shown in Table 3, where savings of around $60 \%$ can be observed. Fig. 14 shows the cash flow over the 25 years of the system's lifetime used to calculate the cost of PV electricity. Maintenance costs have not been included as they are similar in the previous and the current system. It is worth mentioning that due to the large size of the Irrigator Community, it buys the electricity on the market directly, obtaining better prices than other Irrigator Communities and, furthermore, the PV irrigation prototype was small and a kind of home-made system and, therefore, more expensive than a commercial one. Even in this case, the reduction in the cost of the kWh is very significant and allows more savings in market products to be envisaged.

Apart from the environmental advantages, these figures show a significant economic feasibility which opens the door to an important potential market. The irrigation sector for agricultural production in the South of Europe involves individual farmers, cooperatives, Irrigator Communities and agricultural industries, with an estimated total
Table 3

Electricity cost for irrigation in Candela well with the grid and with the PV irrigation system.

\begin{tabular}{llll}
\hline Credit $100 \%$ & Grid cost $(c € / \mathrm{kWh})$ & PV cost $(c € / \mathrm{kWh})$ & Savings \\
\hline 10 years & 13.0 & 5.0 & $61.3 \%$ \\
25 years & 13.0 & 5.4 & $58.6 \%$ \\
\hline
\end{tabular}

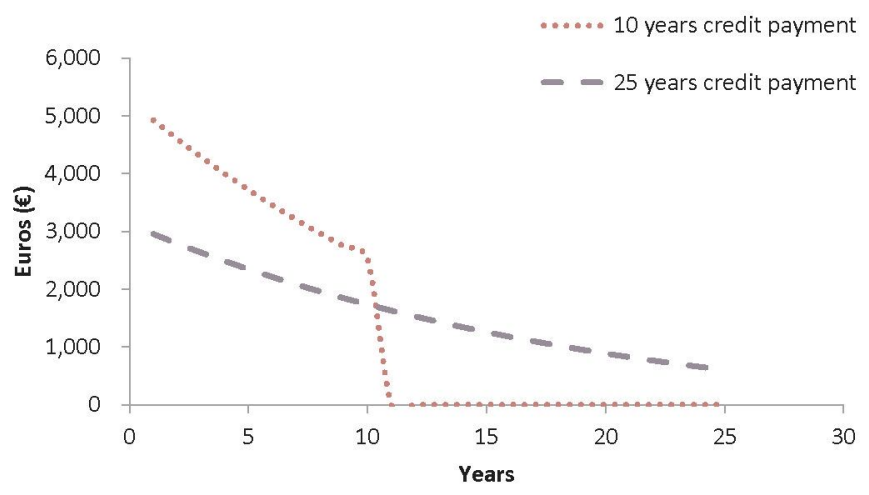

Fig. 14. Cash flow used to calculate the PV electricity cost.

irrigated surface of 14 million hectares, with a total electrical consumption of $24,000 \mathrm{GWh}$. These estimations have been based on several reports from the Spanish Federation of Irrigator Communities, FENACORE $[36,37]$, and of the International Commission on Irrigation \& Drainage [38]. The price paid for the electricity supplied by the grid is increasing dramatically year after year [1].

In order to satisfy this electrical demand, it would be necessary to install $16 \mathrm{GWp}$ (considering a mean PV production of $1500 \mathrm{kWh} / \mathrm{kWp}$ ) of these new PV irrigation systems in Southern Europe [56], with an estimated unit cost of $€ 1.5 / \mathrm{Wp}$, calculated by assuming a reduction in the cost of our prototype when it is built on a real scale. This represents a potential market in the South of Europe of $€ 24,000 \mathrm{M}$ in terms of large

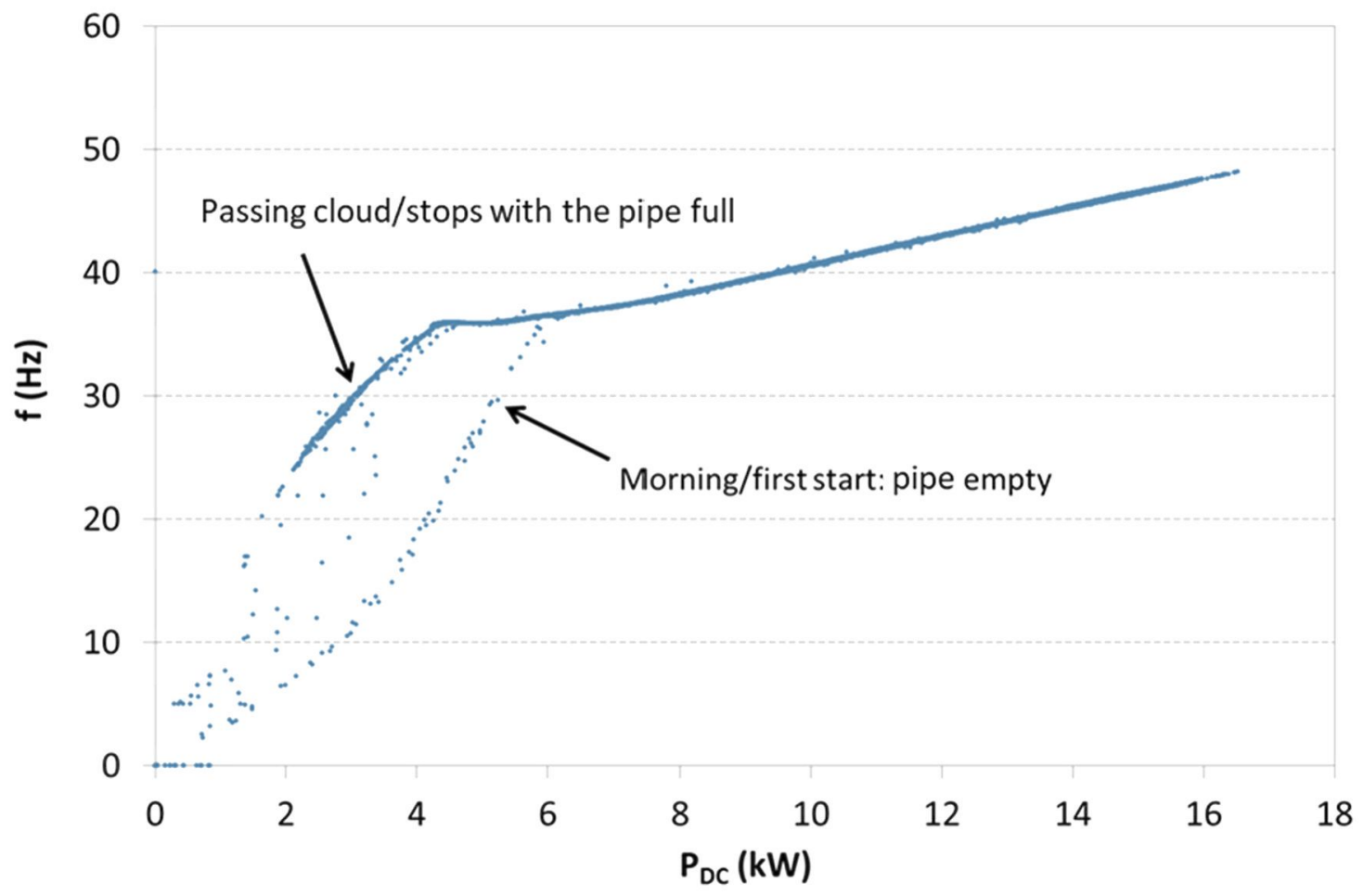

Fig. 13. Relationship between DC power and frequency. 
PV pumps to supply this electrical service.

The market for PV irrigation is not restricted to the South of Europe but also to many other regions in the world where the electrical networks are not so extensive and irrigation in rural areas is covered only by polluting diesel pumps, with a high cost not only from the increasing cost of the fuel but also from the cost of transporting it to disperse areas.

One of the most interesting regions is the South Mediterranean region. For example, Morocco has an electrical consumption for water productive applications of $587 \mathrm{GWh}, 20.3 \%$ of the total electricity consumption for productive activities with an annual increase of $7 \%$ $[57,58]$. The electrical consumption for irrigation in this region is estimated to yield $2500 \mathrm{GWh} /$ year $[59,60]$. This leads to a current potential market of $1.5 \mathrm{GWp}$, which represents a market volume of $€ 2250 \mathrm{M}$, with an expected increase in the range of $7 \%-11 \%$ per year.

\section{Installation and operation of the prototype in morocco}

In January 2014, once the tests carried out in Villena and the technical and economic validations were finished, the prototype was uninstalled and transported to Morocco, to a small village called Tizi, located in the province of Ouarzazate, with the goal of irrigating an area of 30 ha devoted to olive trees, plum trees and saffron. There was a well and a water pool of $10,000 \mathrm{~m}^{3}$ in capacity.

The well is characterised by a nominal water flow of $50 \mathrm{~m}^{3} / \mathrm{h}$ and a total manometric head (HMT) that varies between 70 and $110 \mathrm{~m}$, depending on the season. So, it was necessary to install a new pump (CAPRARI E6S54/8A) adapted to the hydraulic characteristics of the new location. The rest of the components of the prototype remain unaltered. Fig. 15 shows the new location of the PV irrigation system.

Two monitoring campaigns were carried out: the first one just after the installation in the new location, from 12th to 15th February 2014, and the second one three years later, from 30th to 31st January 2017. In both campaigns the $P R$ is close to 0.374 . The difference between this result and the value obtained in Spain is due to the weakness of this well, which experiences wide variations in the water level. This means that the pump operates outside of its optimum working point. Therefore, the characteristics of the well significantly affect the performance of the system and must be carefully taken into account in the design of this kind of project.

During these three years, the local cooperative in charge of the irrigation recorded the water meter readings daily. As a summary of the system performance evaluation, it is worth highlighting that the total volume of pumped water has been $258,562 \mathrm{~m}^{3}$, representing a daily mean of $236.13 \mathrm{~m}^{3} /$ day. The mean water flow registered during our monitoring campaigns was $26 \mathrm{~m}^{3} / \mathrm{h}$, highly influenced by the dynamic of the well, whose HMT fluctuates between $70 \mathrm{~m}$ and $110 \mathrm{~m}$. This also affects the efficiency of the motor-pump, whose mean value was $40.6 \%$. The main technical incidences reported by the cooperative are related to the pump stopping due to the lack of water in the well.

The good response to the PV power fluctuations brought by passing clouds were confirmed, as can be seen in Fig. 16 corresponding to the 15th February 2014, when the frequency was always over zero although the PV power fluctuations are high around midday.

Finally, the peak power of the PV generator was measured before the uninstallation in Spain and after three years of operation in Morocco. It is worth stating that the first measurement was taken after three months of operation of the system, so it includes the initial degradation due to light exposure (LID, light induced degradation). The comparative results are shown in Table 4. As can be observed, the peak power remains the same value and the slight variation is below the uncertainty level of the measurement.

\section{Conclusions}

The use of large power PV generators to substitute the grid or diesel generators to supply electricity to existing irrigation systems in productive agriculture requires two main challenges to be faced: to solve the problems associated to the PV power intermittency and matching the PV production with the irrigation water needs.

This paper has presented solutions to both challenges and their implementation and test on a $20 \mathrm{kWp}$ PV irrigation system installed in a real $250 \mathrm{~m}$-deep well in the Irrigator Community of Alto Vinalopó, in Villena (Spain). For the first challenge, specific algorithms in the PID controller of the frequency converter have been developed and installed, showing that the frequency converter does not stop when a passing cloud reduces the PV power dramatically in few seconds, avoiding any kind of water hammer or overvoltage in the output wiring.

For the second challenge, an North-South horizontal axis tracker (N$\mathrm{S}$ tracker) has been used, allowing an increase in the PV production during the irrigation period (from April to September) and a flat daily profile, extending the number of irrigation hours per day when comparing it with a fixed structure facing to South. The current cost of an N$\mathrm{S}$ tracker is significantly lower than the cost of additional PV modules needed to obtain the same volume of water pumped with the fixed structure.

The economic analysis has shown that PV irrigation systems are feasible and can produce savings of $60 \%$ in the cost of electricity for agriculture. This result opens the door to a huge potential market of $16 \mathrm{GW}$ and $€ 24,000 \mathrm{M}$ in Southern Europe. The market in other regions of the world, with use of expensive diesel generators, is even greater.

Some experimental results of the prototype once it was installed on a real farm in the South of Morocco have been also shown. The PV irrigation system is working as expected, being influenced by the dynamic of the well which, during some periods, is weak and by the lack of water due to droughts.

Although the solution for PV power intermittences can be extended worldwide as it just depends on the maximum cloud speed, the performance of the system depends on the location, the water availability and user behaviour, which opens the door to future research.
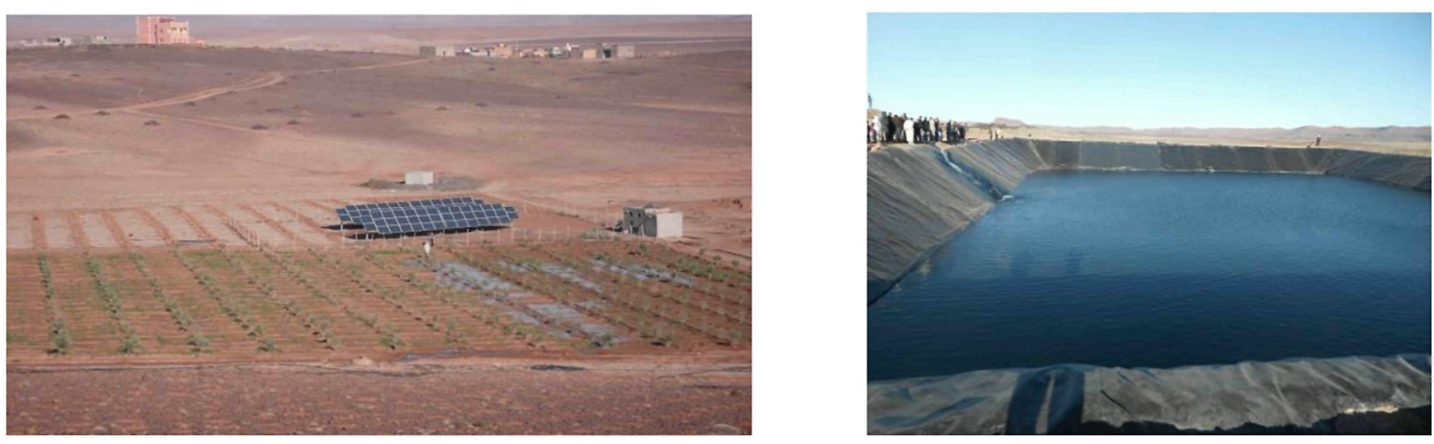

Fig. 15. Different views of the PV irrigation system in Tizi, Morocco. 


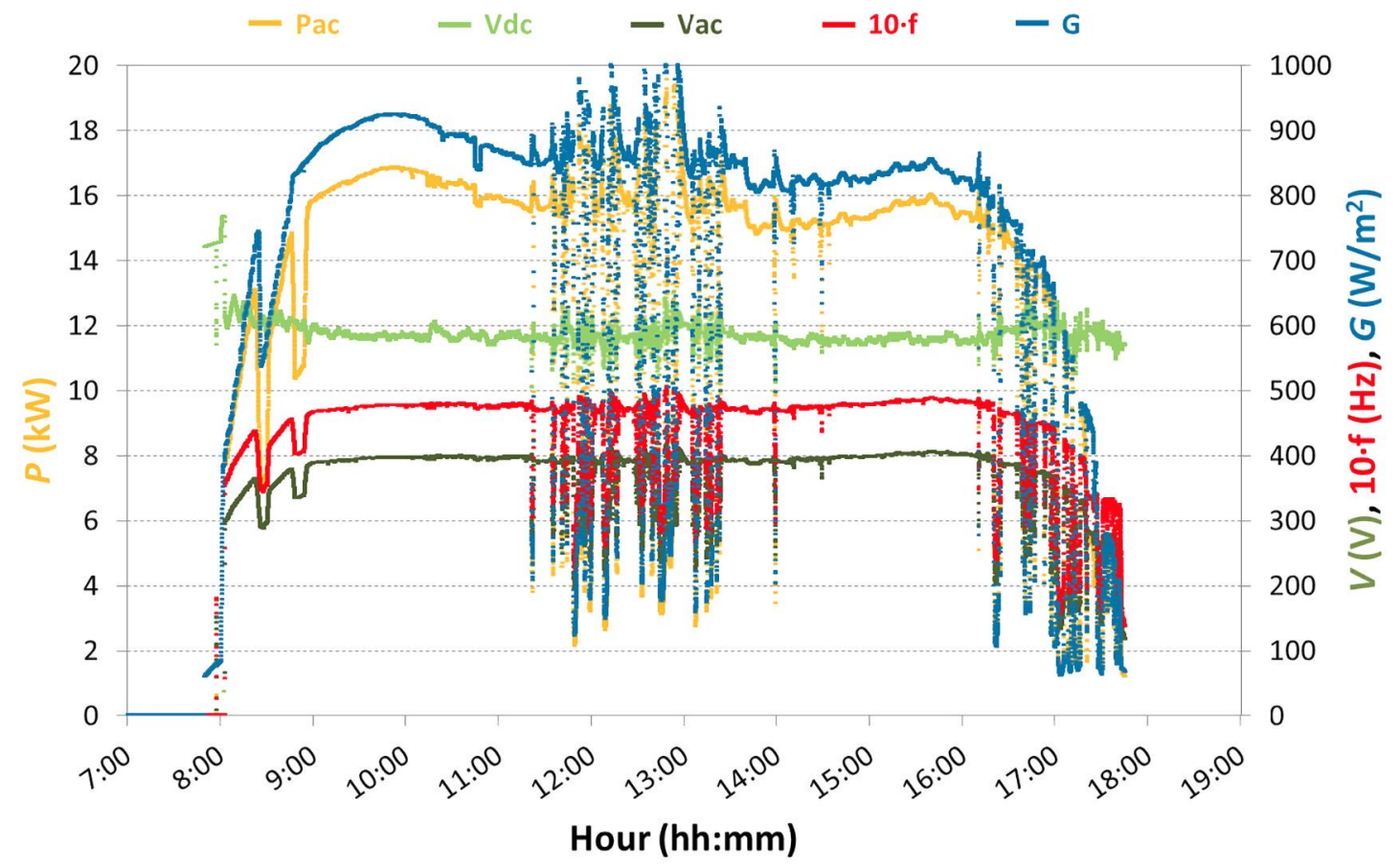

Fig. 16. Main electrical variables of the PV irrigation systems during the 15th February 2014.

Table 4

Measurement of the main characteristic values of the I-V curve of the PV generator before and after its installation in Tizi, Morocco.

\begin{tabular}{lllll}
\hline Parameters & 23rd September 2013 & 28th January 2017 \\
\cline { 2 - 5 } & Mean $\pm \Delta$ & $\begin{array}{l}\text { Deviation from } \\
\text { nominal value } \\
{[\%]}\end{array}$ & Mean $\pm \Delta$ & $\begin{array}{l}\text { Deviation from } \\
\text { nominal value } \\
{[\%]}\end{array}$ \\
\hline $\mathrm{I}_{\mathrm{SC}}{ }^{*}[\mathrm{~A}]$ & $35.1 \pm 0.1$ & -1.4 & $35.3 \pm 0.1$ & -1.0 \\
$\mathrm{~V}_{\mathrm{OC}}{ }^{*}[\mathrm{~V}]$ & $747 \pm 1.0$ & -0.7 & $736 \pm 2.0$ & -2.1 \\
$\mathrm{I}_{\mathrm{M}}{ }^{*}[\mathrm{~A}]$ & $32.6 \pm 0.1$ & -3.6 & $32.7 \pm 0.2$ & -3.3 \\
$\mathrm{~V}_{\mathrm{M}}{ }^{*}[\mathrm{~V}]$ & $573.6 \pm 2.3$ & -2.9 & $570.1 \pm 1.3$ & -3.5 \\
$\mathrm{P}_{\mathrm{M}}{ }^{*}[\mathrm{~W}]$ & $18,686 \pm 80$ & -6.6 & $18,628 \pm 149$ & -6.9 \\
\hline
\end{tabular}

\section{Acknowledgements}

This work has been partially supported by the African Development Bank through the [ACTC-WA2]-ECREEE project and by the European Union's Horizon 2020 research and innovation programme in the project MArket uptake of an innovative irrigation Solution based on LOW WATer-ENergy consumption (MASLOWATEN), under grant agreement $n^{\circ} 640771$.

\section{References}

[1] FENACORE. Bulletin, September; 2013.

[2] FAO. Food and Agriculture Organizations of the United Nations. Economics of irrigation. In Irrigation technology transfer in support of food security. FAO Corporate Document Repository; 1997. http://www.fao.org/docrep/w7314e/ w7314e0h.htm [accessed 07 April 2018].

[3] Perlin J. From space to earth: the story of solar electricity. Michigan: Aatec Publications; 1999.

[4] Vespieren FB. The application of photovoltaics to water pumping and irrigation in Africa. Proc. Europ. PV Solar Energy Conf., Cannes, France. 1980. p. 439-45.

[5] Sontake VC, Kalamkar VR. Solar photovoltaic water pumping system - a comprehensive review. Renewable Sustainable Energy Rev 2016;59:1038-67.

[6] Lorenzo E. Photovoltaic rural electrification. Prog Photovoltaics Res Appl 1997:5:3-27.

[7] Barlow R, McNelis B, Derrick A. Status and experience of solar PV pumping in developing countries. Proc. 10th Europ. PV Solar Energy Conf., Lisbon, Portugal. 1991. p. 1143-6.

[8] Nasir El Hak RA. Expèrience Marocaine dans le domaine du Pompage par Energie
Solaire Photovoltaïque. Proceedings of the International seminar: Pompage Photovoltaique et traitement de l'eau en milieu rural, Ouarzazate, Morocco. 2003. p. 9-14.

[9] Bakri M, Acharai A. Expèrience Marocaine dans le domaine du Pompage par Energie Solaire Photovoltaïque. Seminaire International: Pompage Photovoltaïque et traitement de l'eau en milieu rural, Ouarzazate (Maroc), 2003.

[10] SMAP. Implementation of a PV water pumping and purification program in Mediterranean countries, (2001-2005). Contract ME8/AIDCO/2001/0132/SMAP4, SMAP Program. European Co-operation Office; 2005.

[11] Hamidat A, Benyoucef B. Hartani T. Small-scale irrigation with photovoltaic water pumping system in Sahara regions. Renewable Energy 2003;28:1081-96.

[12] Hoang-Gia L. Revue des programmes d'approvisionnement en eau potable par pompage photovoltaique en Afrique de l'ouest. Workshop on PV water supply system improvement, Marrakech. 1998. p. 45-50.

[13] Cota AD, Foster RE, Gómez LM, Ross MP, Hanley CJ, Gupta VP, Montúfar O, Romero A. Ten year reliability assessment of photovoltaic water pumping systems in Mexico, solar 2004. Portland, Oregon: American Solar Energy Society; 2004. p. $113-8$

[14] Moore L, Post H, Adams K, Malczynski L, Hauck R, Jesperson T, Skinner R, Anderson J. Operation and maintenance field experience with photovoltaic water pumping systems. Proceedings of ISEC 2005, Orlando. 2005. p. 1-5.

[15] Fedrizzi MC, Zilles R, Noda H. PV systems implementation experience in the Brazilian amazon rain forest. VI World Renewable Energy Congress. Brighton: UNESCO; 2000. p. 875-8.

[16] Fedrizzi C. Sistemas Fotovoltaicos de Abastecimiento de Agua para Uso Comunitario: Liçoes Apreendidas e Procedimientos para Potencializar sua Difusao [PhD. thesis]. Brazil: University of Sao Paulo; 2003.

[17] Kaunmuang P, Kirtikara K, Songprakorb R, Thepa S, Suwannakum T. Assesment of photovoltaic pumping systems in Thailand - one decade experience. Sol Energy Mater Sol Cells 2001;67:529-34.

[18] Tiwari AK, Kalamkar VR. Performance investigations of solar water pumping system using helical pump under the outdoor condition of Nagpur, India. Renewable Energy 2016;97:737-45.

[19] Kenna J, Gillett B. Solar water pumping: a handbook. IT publications. IT power in association with Sir William Halerow and Partners. UNDP - World Bank Solar Pumping Project GLO/80/003, London; 1985. p 36-49.

[20] Narvarte L, Lorenzo E, Aandam M. Lessons from a PV pumping programme in South Morocco. Prog Photovoltaics Res Appl 2005:13:261-70.

[21] Hahn A. Photovoltaic water pumps. Lessons learned from demonstration and field testing projects supported by GTZ. Workshop on PV Water supply System improvement, Marrakech. 1998. p. 39-44.

[22] SOPRA-RE. Social practice for renewable energy systems in rural electrification, Project number 4.1030/Z/01-086/2001. European Commission; 2001.

[23] CILSS. Appel d'Offres Restreint. Programme Regional d'utilisation de l'energie solaire Photovoltaique dans les pays du Sahel. Ouagadougou, Burkina Faso: CR-VI FED: 1989.

[24] Kabore F. PV Energy for a sustained and social development in the Sahelian Region. The regional solar program. The yearbook of renewable energies. London: James and James; 1994.

[25] Liebard A. Regional solar programme. Lessons and perspectives. Paris: Fondation 
Energies pour le Monde; 1999.

[26] Narvarte L. Poza F, Lorenzo E. Specification and testing of PV pumas for a Moroccan project. Prog Photovoltaics Res Appl 2006;14:733-41.

[27] Alonso M, Lorenzo E, Chenlo F. PV water pumping systems based on standard frequency converters. Prog Photovoltaics Res Appl 2003;11:179-91.

[28] Brito AU, Zilles R. Systematized procedure for parameter characterization of a variable-speed drive used in photovoltaic pumping applications. Prog Photovoltaics Res Appl 2006;14:249-60.

[29] Tiwari AK, Kalamkar VR. Effects of total head and solar radiation on the performance of solar water pumping system. Renewable Energy 2018:919-27.

[30] Valer LR, Melendez TA, Fedrizzi MC, Zilles R, Moraes AM. Variable-speed drives in photovoltaic pumping systems for irrigation in Brazil. Sustainable Energy Technol Assess 2016:15:20-6.

[31] EIP-Water. Priority area P30: water-energy nexus. European innovation partnership on water boosting opportunities - innovating water; 2013. http://www.eip-water. eu [accessed 07 April 2018].

[32] Patent ES2607253B2. Procedimiento y dispositivo de control para sistemas de bombeo fotovoltaico; 2017.

[33] Narvarte L, Lorenzo E. Tracking and ground cover ratio. Progress in photovoltaics. Res Appl 2008;16(8):703-14.

[34] Lorenzo E, Narvarte L, Munoz J. Tracking and back-tracking. Prog Photovoltaics $2011 ; 19(6): 747-53$.

[35] AECID. Desarrollo de sistemas FV de bombeo de alta potencia para aplicaciones productivas de riego (Oct 2011-Apr 2014). 2014.

[36] FENACORE. Informe sobre las tarifas eléctricas del regadío en España Available at 2012www.fenacore.org.

[37] FENACORE. Las tarifas eléctricas del regadío. Cronología, problemática y soluciones Available at 2017 www.fenacore.org.

[38] International Commission on Irrigation and Drainage. Agricultural water management for sustainable rural development, Annual report 2016-2017.

[39] Astrom KJ, Hagglund T. Advanced PID control. Pearson - Prentice Hall; 2009.

[40] Alonso Abella M, Lorenzo E, Chenlo F. PV water pumping systems based on standard frequency converters, progress in photovoltaics. Res Appl 2003;11:179-91.

[41] Shmilovitz D. On the control of photovoltaic maximum power point tracker via output parameters. IEE Proc Electr Power Appl 2005;152:239-48.

[42] Tafticht T, Agbossou K, Doumbia ML, Chériti A. An improved maximum power point tracking method for photovoltaic systems. Renewable Energy 2008;33:1508-16.

[43] Brito AU, Fedrizzi MC, Zilles R. PV pumping systems: a useful tool to check operational performance. Prog Photovoltaics Res Appl 2007;15:41-9.

[44] International Energy Agency. Trends 2016 in photovoltaics applications - survey report of selected IEA countries between 1992 and 2015, Report IEA PVPS T1-30; 2016.

[45] Baumgartner F. 5 - Photovoltaic (PV) balance of system components: Basics, performance, Nicola Pearsall, The performance of photovoltaic (PV) systems. Woodhead Publishing: 2017. p. 135-81.

[46] Khadidja B, Dris K, Boubeker A, Noureddine S. Optimization of a solar tracker system for photovoltaic power plants in Saharian region, example of Ouargla. Energy Proc 2014;50:610-8.

[47] Martínez-Moreno F, Lorenzo E, Muñoz J, Moretón R. On the testing of large PV arrays. Prog Photovoltaics Res Appl 2012;20:100-5.

[48] Marcos J, Marroyo L, Lorenzo E, Alvira D, Izco E. Power output fluctuations in large scale PV plants: one year observations with one second resolution and a derived analytic model. Prog Photovoltaics Res Appl 2011;19:218-27.

[49] Marcos J, Marroyo L, Lorenzo E, García M. Smoothing of PV power fluctuations by geographical dispersion. Prog Photovoltaics Res Appl 2012;20:226-37.

[50] SISIFO simulation tool; 2013. https://www.sisifo.info [accessed 07 April 2018].

[51] Smith S. PV trackers. SolarPRO Mag 2011(4.4).

[52] Fu R, Feldman D, Margolis R, Woodhouse M, Ardani K, Solar US. Photovoltaic system cost benchmark: Q1. National Renewable Energy Laboratory; 2017.

[53] IRENA. Renewable power generation in 2017. Abu Dhabi: International Renewable Energy Agency; 2018.

[54] Kost C, Shammugam S, Jüilch V, Nguyen H-T, Schleg1 T. Levelized cost of electricity renewable energy technologies. Fraunhofer Institute for Solar Energy Systems ISE; 2018.

[55] IEC 61724-1. Photovoltaic system performance - Part 1: Monitoring. 2017.

[56] Estimation of the authors based on the report 2016-2017 of the International Commission on Irrigation and Dreinage and estimations of irrigation land of the Euro-Mediterranean Asociation of Irrigator's Communities.

[57] IEA. Morocco: electricity and heat Available at $2015 \mathrm{http} / / /$ www.iea.org/statistics/ statisticssearch $/$ report $/$ yyear $=2015 \&$ country $=$ MOROCCO\&product $=$ ElectricityandHeat.

[58] Ministère de l'Énergie, des Mines, de l'Eau et de l'Environment-Royaume du Maroc, Département de l'Énergie et des Mines, Direction de l'observation et de la Programmation, " Analyse des Indicateurs Energetiques - Efficacité énergétique dans le secteur Agriculture au Maroc »; 2013. p. 76-82.

[59] Ministère de l'Economie et des Finances-Royaume du Maroc, Département des Etudes et des Prévisions Financières, «Quel positionnement régional pour le Maroc en matière de compétitivité énergétique? »; 2015.

[60] Ministère de l'Énergie, des Mines, de l'Eau et de l'Environment-Royaume du Maroc. «Stratégie énergétique nationale horizon; 2030. 